\title{
Storage characteristics, digestibility and nitrogen balance in west african dwarf sheep fed preserved elephant grass, eaged layer waste and cassavin peel fliets during dry season
}

\author{
O. S. Sowande, A. B. I. Aina', F. B. Orguntona ${ }^{2}$, A. O. Fanimo', F. A. Ademole' \\ and O. A. Adesauva!

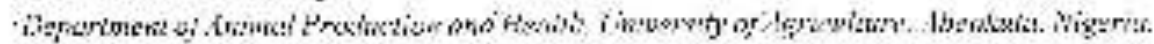

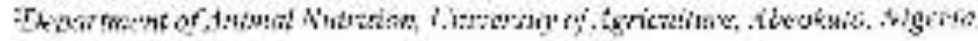

\begin{abstract}

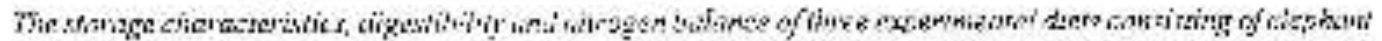

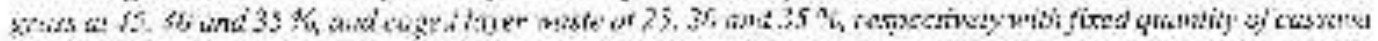

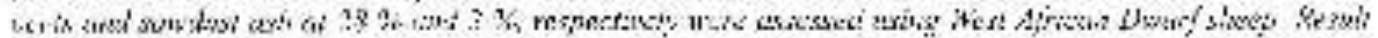

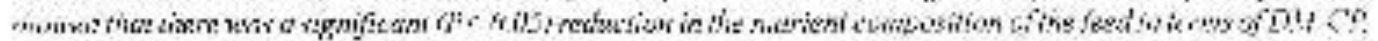

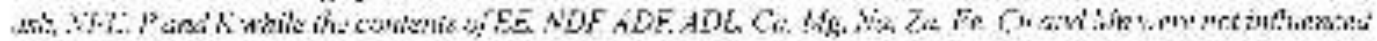

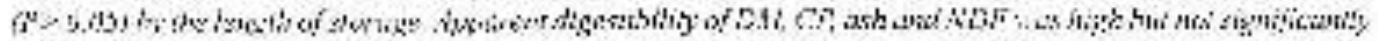

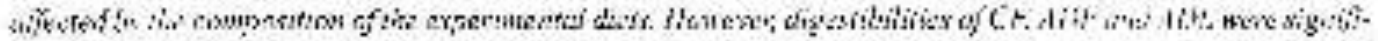

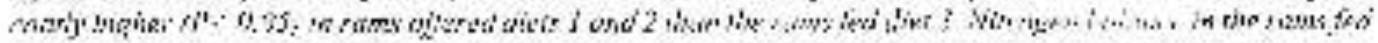

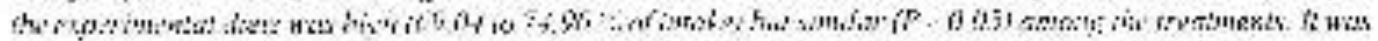

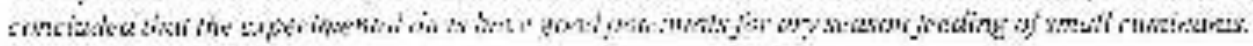

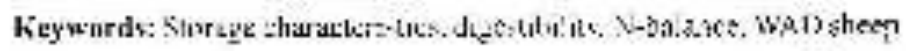

\section{lntrisduction}

Ote of the mast impotiant tictors determinimy the profitabiling of any ivestocx enterprise is optimal level of feating. This aim js trosl prob lamatic to achicved cirirg the dry seivon wilen available tiend is scarce and of low norritive celail. ity Adejume and hudemosun. 1955, Davies and

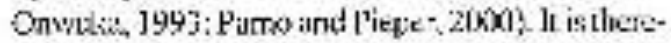

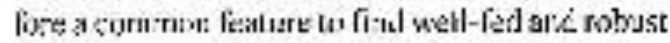
strall n-munanis in the tainy season to have appreciasly fos weight in the following ciyscasor. (Vrolhwe:1, 1972; Pagor, 1992; Adezbola, 199S). I he challe-1ge io Animal Scicntists ard restarchars is fecd pooduction end uilization in the dry: seasun to sterr the cyclic pattern el wight gait ard loss berween sasisons. Elepianl grass

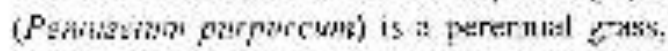
whicin when hareat ed young could bo preserved a* a major source of licditer for small :uminzsss in the dy seaso: 1. Most studies on the utilization of this grass have focuse? on ils use as bilys and

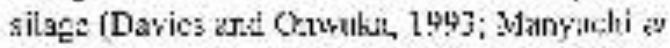
a.. 1996; Mrvirue el ad. 1998; Sartrit an:3 Nisil, 1999). Large quantities ol cinged lay $=r$ wasle are

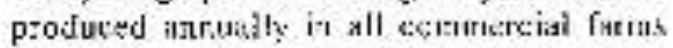
(fonteoot, ( 949 ) and ilnsy tonsrimts a buisance to the eaviruriruen hy ptescating disnosal yoobern where tiey are iut used as menure (Mulice. 19811 . Caged layer waste is a rich source of proseiru tangiag, berkeen $25-30 \%$ crude prot:in of which .60 - $59 \%$ is true protein (Koyonge ef $2 i$., 1993) that cen bo utilized by ruminants to pro-

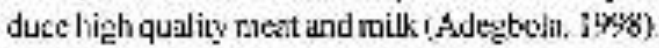

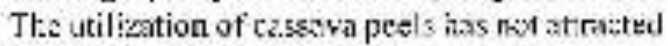

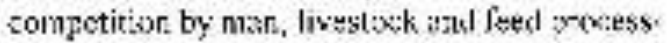

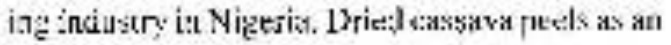




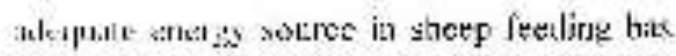
heen revoented Addchowais, 19g1; Adegboli

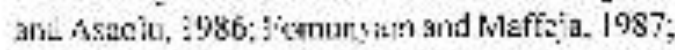
Okendo and Autegbole, 1345 , tn 1he present study the slorige ciraacteristics, nu.rjent digestioility and nitrogen balance in Wiest Atrican tharl streep ted ciets wristuly, of difereat combinsiuns of drict clept.unt geass. tiened leje wast:

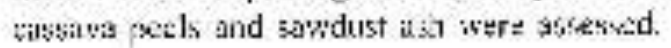

\section{Mhaterials and Methods}

\section{Expoptansenta' sive:}

The exferiment wiss bonducted at the Smail Ru-

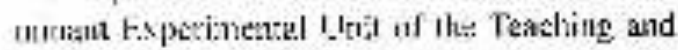
Rejeilrch liarm. University of Apricultare, Abcokutat. The lecarion. which is $76 \mathrm{~m}$ abores seat level. falis within lasti!utes it $5.54-7 \times 8.0 \mathrm{~N}$ and longitules $3^{\circ} 11.2-3^{0} 12.5^{\prime} 1:$ The clianate s.s hmid and is locsed in the surived git v; this zone of

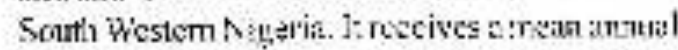
precipitar:or af 1.037 mun, nean annual :conpersture of $34 . \%$ C and aces relative bum rity of 82 s..

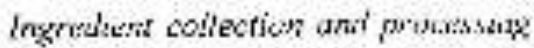
Eleritarit quas (after 6 to 8 wots iegristh) was ha:resled iluog the Teaching and Research hasm of the Unwersity of Rgriculsuc, Abeokuta. $1 \%$ -

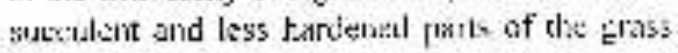
were sut, chepped with a. shotp sutliss to about

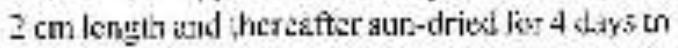
abot: $30-15^{*} \%$ musishure conter.1. The drietal giass wist then pecked into steks untii readed.

Fresh earent thye: waste wos collec: al from tre

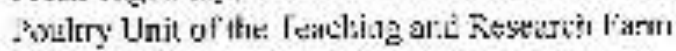
of the ? nniversicy of Aerieulture. Alscoktta. The troppings wese sun-jried ol black pelychese nylon for 8 days. As the dryite pris; lun ps were mumbily er ushod to reưuce de par. lic:le sins. The drisd droppings wore thereafier pucked :at sacks uatil aeedet.
Fresh cassuva peels were teollecled from differant gari-processing lowatuse around the Abeckute Townstip. Ibe poels ware spread on omkicte flows und sum drying was done for 3 dey' after which the perts were packed initu saciks. Fresin wood ash trom biret sowisibl wias collecad [rolly a sawnil]. The ash was sieved la poss lituogh a $1 \mathrm{~mm}$ acreen to segoove extratenus insterials.

\section{instedtent wixng and stowg:}

Threc experimentisl diels consisting of stephant press at 15.40 ard $35 \%$ and coged liyer wase at 35,30 and $35 \%$. zespextivis with fxull quantity oÉ cassavn pecis and sirvdest asli ar $28 \%$ and 2

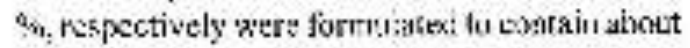
$17.00 \%$ crude protein (Tilele ]). Sismlust is h was t.eed as a mineral sounce (Sowande ot ai, 2002). the erass was poured tirst folleweid by poulay

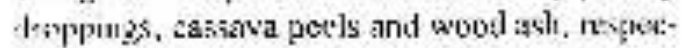

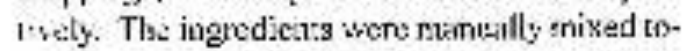

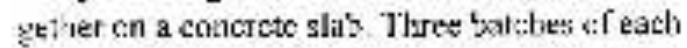

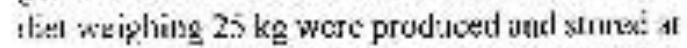
num t.mpetaturc for threc monthis (Septentier to Decerr ber) in a well-weotidate 3 roor:

\section{Digestibility und sitngen baiance th:}

Vine rems: weighing $14.5=0.7 \mathrm{~kg}$ and 38 ronths wi alge, were usew for tl:e digentibility and nitosEen $(\mathrm{N}$ ) balante; trials. Thres rams were allotled to each of the resened dict at 30 dzzs of stur-

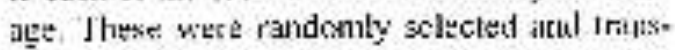
terad to ind s idual metabolison coge atlowing fur separate collection of faces and urire to sleter. mine ot trieral dignestbiling and $\mathrm{N}$ bolance in the rams. The zilerus were mainssined at $4 \%$ of thei-

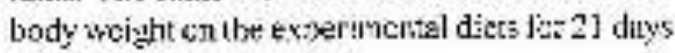
with firec acoess tu waler.

Tazo sollection

Sampling from oacs batch of fexcl was some inmediately afte: feod mixingr. Subsejaently sem- 
pling was dowe on monthly uxasis. Durizg each samplung, callectioa was made tions the kij: middle and botton ol the bags after goastial starin:

The rams were allowed 14 days antjusticht p:sivd ixcore T-day wotal collection of fitetch and urine. Faccal colles:tien from each rasisi utas oven dried a: $65^{2} \mathrm{C}$ for ' -1 hr., weighes!, hulked anu aliequors $(254$ it was taben from individaal animal fer chemucist analysis. Urire sampies vere copt. lecled ia uria sample bonles picviously rinod with dihux sulpheric in:us ( 10 \% $6 \mathrm{H}_{2} \mathrm{SO}_{3}$ ) ta preserve nitrogen. Total volume sas ciet:rantres! yad 754 in inoted in the detp fiecrer at $-20^{\circ} \mathrm{C}$ until requircd tor ciemut:al analysis.

\section{Chawicut anabyiv}

The encoss enerpy of the feeds was deteminat using Gallenkamp adiabatic bomì calor.meter (CBA - 305). The proximate cennon iston of feed and foecal samples as well is ritries en in unio Aas topleriaind (A. O. A. C., 1990). The surns

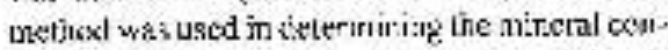
cenuartm: in foed and lasces samenles. Deterniv

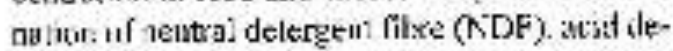
tergen fibre (ADE) and acid derergent tignin (AD) ; was by the relelsed of Goering and vat Stest $\{19: 0)$ -

\section{Starisizal anabssis}

All the data generited were sublested to oneway analysis of sariance in a completely sallumizeil design usizg Ute statistical package (SISS. 16,y) while signufworly different meirns weec separated 19ing Duscan (1955) Multiple Kaage | tur relatir.g the chest tol co:mposition a rit focd 10 length vi storage was derived sy 'itting the sopthiy walues of tote various chericil cumpo-

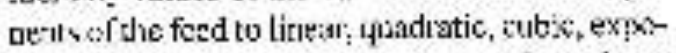
nentiat al'd pouer functions. Test of guvelsess of tit was leased on ccefficitent of deremination
( $\left.{ }^{2}\right)$ walues. The cetbic fimcijun was selected is having the best fit.

\section{Results}

The cheraix:t emposition of the experimentst? diens lest to hest Afican Dwarf stoep is pre scnted in Iisble I. Dry matter combents of the strcts varied helween $90.27(\%)$ and $90.62 \%$. Coude protein content increasut as the percentage of poultry (layer) droppings increasoa from $17,44 \%$ in diel i to $18.73 \%$ in alies. 3. The CF in the diat Jecicased in line with the reduction in lste ismonent

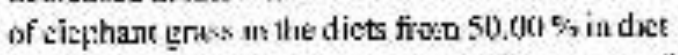
1 so $34.67 \%$ in diet t. The EE and ash courtents of Ite dicts de:creiseral irspectivcly trum $1.4 ; \%$ and $9.69 \%$ in ciet 1 10 $1.31 \%$ and $893 \%$ in diets. Nitrogen tres exlracl increased liont $21.46 \%$ in lict 1 to $36,36 \%$ in dict 3 . Tbe NIS, ADF and ADL conters of the dicts followed similar trent

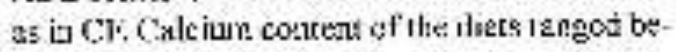
ven ! $53 \%$ and $1.70 \mathrm{~m} / \mathrm{s}$ while tl:s concentrittivis of $\varphi$ and $M g$ retluxed respectively finm 0.38

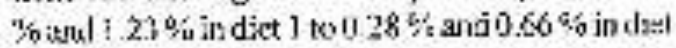
3. Puassium content of the dies ranged from

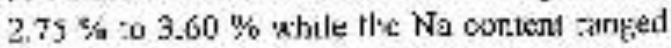
trestwent $0.85 \%$ anx $1.30 \%$.

\begin{tabular}{|c|c|c|c|}
\hline \multirow[b]{2}{*}{ trie:ts } & \multicolumn{3}{|c|}{ ross } \\
\hline & ! & $\underline{2}$ & st \\
\hline Drg :unks & $x_{1}: i_{2}$ & 953 & $\overline{x i} \div$ \\
\hline Conkijucts. & 174 & 1492 & 187 \\
\hline Crxb:tibs & प्र:18, & S: & $34 x$ \\
\hline Dhor was: & $1+1$ & 1.34 & $1.3 \mathrm{~L}$ \\
\hline sis & $7 \leqslant$ & vx: & 893 \\
\hline Notugen biv : stiser & 21.40 & $: 4.15$ & J5:5 \\
\hline 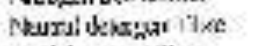 & 3513 & $77: 2$ & $7 \times 19$ \\
\hline 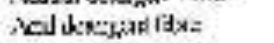 & 3324 & IE In: & $250 \%$ \\
\hline red dokngul listin: & 2618 & ?AIr & 1836 \\
\hline inciur: & $1.7 \mathrm{~m}$ & 13 & 1.0 \\
\hline Pos: xras & 0.18 & 0.54 & al \\
\hline tonesiam, & 1.2 & $a x$ & Itit \\
\hline Gremst.m & $3(0)$ & 273 & ;.1. \\
\hline Evistat: & 13 & as! & $12 \%$ \\
\hline 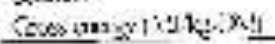 & $18 \leqslant 4$ & $18 x$ & 3831 \\
\hline
\end{tabular}




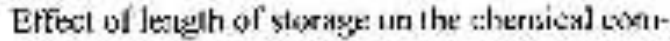
position of the experinsental diets is pxesented in Tible 2, Sturisk levigth significantly influcned (P-Tios) the cluenical compesition of the food in terms of DM, $\mathrm{CP}$, asi and NFE. The DM in diets: and 3 w'as lower ( $\mathrm{P} 00.05)$ at 90 day's than ut 0 day while the reverse was the crend in diet 2 at 0 and 90 days of storage. The CP conterts of each of the dict roiucod $(\mathrm{P}<0.05)$ with increas!ng length of storage. Diet 3 had sigcuticablis higher $\{P<0.05$ )

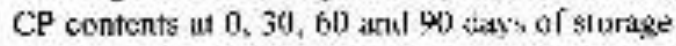
laun both dirt. I and 2 . There was a general redurtion (Peo. 0.5 ) in the ash contents of the thece

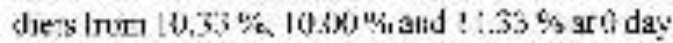
In $495 \% .5 .94 \%$ and $5.95 \%$ Iespectively for diets 1,2 and 3 . The RFE ontents of diets 1.2 and 3 iacreased $(1+20.05$ ) from $20.56 \%, 35.24 \%$ al $133.80 \%$ ta $47.76 \% 49.57 \%$ and $56.05 \%$ espretively. The content of EE, NDF. ADF ane. A:jl. of the dists were rot signiticanty irtlueseced (1).0.05) by the lergth of strorage. The corienmations of $\mathrm{Ca}$.He. Na, $\mathrm{Zn}, \mathrm{Fe}$. Cu and $\mathrm{Stn}$ were not aigniticantly intherced (P:00.05) by the iengrh of storage although tivere wiss a geveral decline in the amount of these minerzls as storage advanced. Potassium concentration in diat 3 at 60 inys of storage was signitivantly hister $(P \% 0.05)$ compared to the $\mathrm{K}$ content ot orher diet. There was a decline $(\mathrm{P}-j) .05$ ) in the corxentration of $K$ in diess $]$ and 2 respectively ficm $0.25 \%$ and 0.40 $\%$ at 0 dny to $0.18 \%$ and $0.26 \%$ at $\%$ dsyz of storage. Potassium contents in dies 3 did nor follori sl consistent perter. Dies 1 hat the lewest wnentration of $K$ at $0,30, \forall b$ ind 90 dilys of storage compersd to other diess.

Poranerer estimiles for gredicting the cbemical consxwition of the feed during prolonged lengh

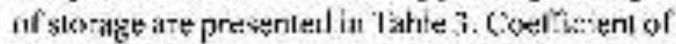

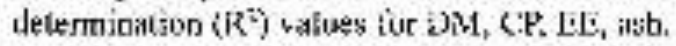

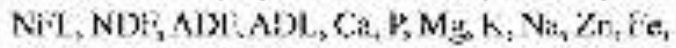
Cu and Mn are showr
Apparent mutricant औigestibilities of the experimental diets in West Aitican Dwart sneيp are presented in Table 4. The is ry rnatler stiges ability in

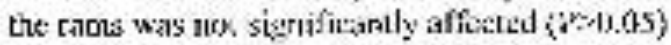
by detary sceiturenls. The bighest 13M digcstibj iny of $71.76 \%$ wis fenrul in rants offered diet? while the owess (fif. $6.5 \%$ is was foud in rants fod tiel 3, Crute protein digestibilty in the rans a

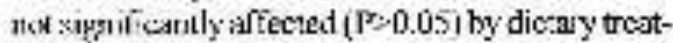
Iselit. Y lowerex, the highest CP digestibilicy was ohsered in dict 2 end the least in diet 3 . There was signiticant trestnent ettect $\left(\mathrm{P}-\gamma_{2} .05\right.$; un be apparent dicestibility of ende tibre. The rams led dict 3 had the lowest (P $\times(.05)$ of sligestibility. Th: rams oftiered dists $l$ and 2 , as well as tioge tod diets 2 and 3 had similar $(P: 00,05) \mathrm{Cl}$ digestibility shile the rams fed diec I had a sisnificutly

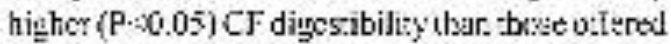
dict 2. As.1 and NDF diges:ibilities were not sis-

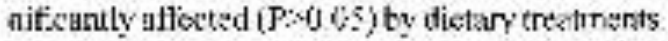
However. there was u dexrelise in ash digestitility from $68.68 \%$ is diet $\vdots 1560.56 \%$ in dat 3 Neutral detergect fibre digestibilaty ajso deeneased from 60.39 \% iz diel l so $50.01 \%$ in diel 3.

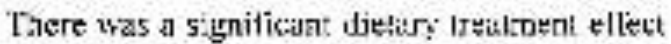

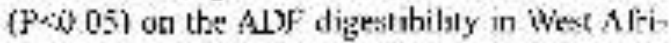
can dwite rams foul the exper ment lisi diels As:it? detergent libre dugestibitity of tans fed djec 3 was:

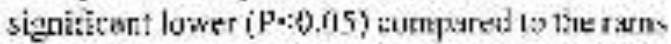
fed obber diel. The saros fed diets 1 and I lail

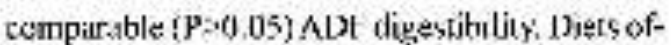
fered significantly atfiev:lat the ADi. tigns:abilily in West Afrisan dwarl rarns. Digestikility of ADL. was simalar ( $P>0.05$ ) in rans fed diels 1 anke 2 irhile the digestipilily of ADI. in rangs offered diet 3 was sigaificantly luwer: (P).015) collipareal all thise led diels : and 3 .

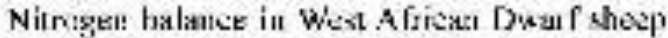
fe: the experilsental diets is prosented in Table $S$. Nilngen (N) intake was ust differenc ( $1>0.05$ ) in lie rarns fext Ile experimel:tal diets. Tloz highest 


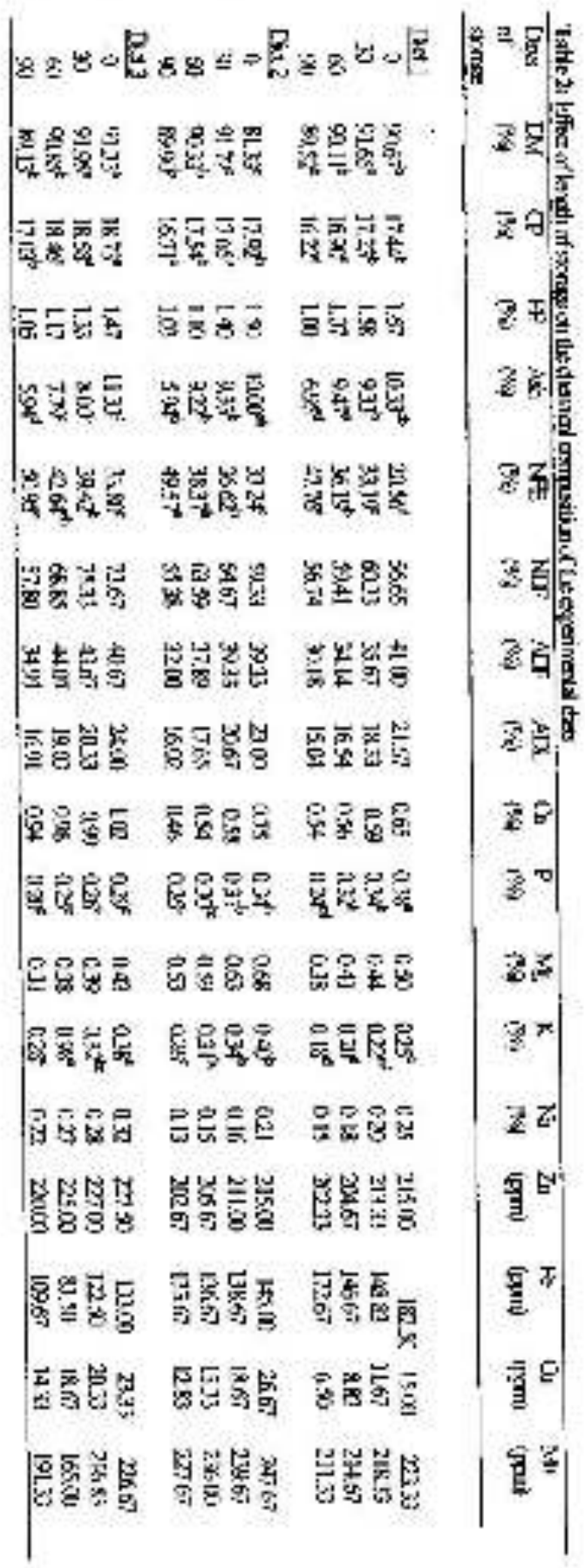


'Table 3: Cubic regression equation $\left(\mathrm{a}+\mathrm{bx}-\mathrm{cx^{2 }}+\mathrm{a} \mathrm{x}^{3}\right)$ reiatilg chemical compuxition

\begin{tabular}{|c|c|c|c|c|c|}
\hline \multirow[b]{2}{*}{ Variables } & \multicolumn{2}{|r|}{ Diets } & \multicolumn{3}{|c|}{$\mathbf{R}^{2}$} \\
\hline & & $\mathbf{h}$ & s & d & \\
\hline Dry rnaller & 87.778 & 8.596 & .5 .556 & 0.465 & 0.24 \\
\hline Crude protein & 18.029 & .0 .488 & 0.416 & -0.13 .5 & 0.49 \\
\hline Etber exiracl & 1.57 & 0.144 & 0,328 & 0.074 & 0.73 \\
\hline Asho & 10.556 & -3.830 & 2.3 .44 & $=0.6 \mathrm{RI}$ & 0.81 \\
\hline Nitrogen ftee extract & 792012 & 13.563 & -8.348 & 2.041 & 074 \\
\hline Nevitral detergent fibre & 63232 & 7,379 & -1.139 & 0716 & 0.21 \\
\hline Ackd delergeist fibre & 4k.??3 & -2.533 & 2660 & -0.962 & 0.38 \\
\hline Asid detergent Jenin & 22.889 & -3.4019 & 0.929 & -0.131 & 4.82 \\
\hline Culciust & -0.8016 & 0.144 & $0.07 \mathrm{i}$ & .0 .014 & 4.07 \\
\hline Phosphord & 0.334 & -0.063 & $0.51]$ & -0.011 & 0.52 \\
\hline Maerresium. & 0.537 & 0.074 & $0.02 \%$ & .0 .0066 & A. 19 \\
\hline Po:aesium & 0.347 & -0.421 & 0.487 & $-\Omega 119$ & 0.22 \\
\hline SoJjun: & $0.25 \mathrm{~b}$ & -10.077 & 0.042 & $\triangle$ S. IIUS & 0.52 \\
\hline Zinc & 219.157 & 1306 & -4.222 & 0.861 & 0.21 \\
\hline irvil & 153,500 & -7.610 & -14.278 & $5,0,56$ & 0.11 \\
\hline Copper & 21.657 & -6.731 & 2.389 & -4.435 & 0.39 \\
\hline Marigallese & 232556 & 10.685 & -24.413 & 6.130 & 0.18 \\
\hline
\end{tabular}

Tiarle A: Apperent mutrient digestibility of the exacrimental diets fed to west Atrit:an Dwirt: jleep $(\%)$

\begin{tabular}{|c|c|c|c|c|}
\hline \multirow[b]{2}{*}{ Nuxicnt: } & \multicolumn{4}{|c|}{ Dicts } \\
\hline & I & $\overrightarrow{2}$ & 3 & + SEM \\
\hline Dry mattes & 67.97 & $716 \%$ & 66.63 & 0.235 \\
\hline Cnule motsin & 73.23 & 76.72 & 73.45 & 0.899 \\
\hline Crude tibes & $69.22^{\prime}$ & $61.94^{\prime \prime}$ & $\$ 1.48^{6}$ & 0.309 \\
\hline Ash & 68.68 & 67.07 & G0.56 & 0,390 \\
\hline Vettrul dettergenal fibfo & 60.39 & 59.72 & 50.01 & 0.527 \\
\hline A cill delargent filme & $64.01^{2}$ & $66.38^{3}$ & $57.08^{k}$ & 0.435 \\
\hline Acid detergent liggin & $86.42^{e}$ & $74.67^{\prime}$ & $60.64^{t}$ & 0.536 \\
\hline
\end{tabular}

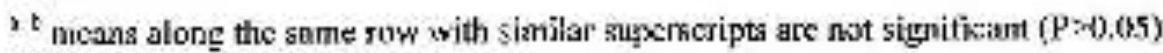
SEM - Stitratard error of Ineans

Nintake was from diel I wilile the least $u$ s from dict 3. There was no sipnificant effect ( $P>0.05)$ atrijbutable to dietary treatrnept on faccal and srinary cxcretion of N, Faecal and urinary excreLin of $\mathrm{N}$ followed similur trend as ubserved in intake. Nitrogen absorption and retertjon wese uot signilicam ly aftected ( $\mathrm{T}>0.05$ ) by dictary trulmeot. Nitrogen absorption w'ns highest in rams sttered diel 2 and lowest in those fed diet 3 . How iver, wheu expressed as percentage of jutake the rams fed diet 2 still had the highest Nabsorption ard the least was in diel 1 . The highest $N$ reten- 
Table 5: Nitroger balance of West Attican Owat sheep fod the experimental dicts

\begin{tabular}{|c|c|c|c|c|}
\hline \multirow[b]{2}{*}{ Ireoss } & \multicolumn{4}{|c|}{ Dners. } \\
\hline & $i$ & 2 & 3 & + SEN \\
\hline Intake (gidatis) & 76.39 & 72.48 & 67.62 & 0.399 \\
\hline S:xcietion (Eday) & & & & \\
\hline Fię:il & 22.19 & 16.86 & 16.08 & 9.302 \\
\hline Urinar: & 1.16 & 1,86 & 1.17 & B.onta \\
\hline Alssception (y'duy) & 94.20 & 5.52 & 51.54 & $0.14 \%$ \\
\hline "\%o intake & 7095 & 76.67 & $76.2 \%$ & 0.292 \\
\hline Retentisu (giday) & 52.74 & $54.3 t i$ & 50.37 & 0.183 \\
\hline$\%$ ou izunste & 69.04 & 74.90 & 74.49 . & 0.297 \\
\hline
\end{tabular}

SEM - St:Judiad wror of n:eats

Lion of $\lrcorner 4.36$ edd was reconded in rains fed dict 2

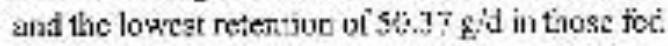
cict 3. Wien expreised a peresitoge of intake the rims fec diex 2 still bad tive ذigriest $N$ rælen-

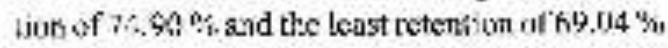
was in dict 1.

\section{Diveussion}

The CP and C[ ionlents of the expeximatsal dicts are retlesticas of the reletisc proporticns o: leyen;' dropping and elcphant eress Tbe CP in ereased as the proportion of loyess droppings increased in the dies wibile the crude fixe retheed as the quentity o: elephant grass docreasod in the eicts. The $\mathrm{CP}$ acd CF in the prosent stuty are bigher than thexe reported by Oladotun et ril. (2003). These arise from the differences in the propertion of iaycts' droppings used as well it difierent type and quantity of grassess used in the rwo studies. The Lbore tnetiuns of rlie diets wers very Ligh and terresest ss the proportion of elepszat grass in the dier decreasod. Mpairk: et al. (1998) reported high NDF and ADF ovo: len is for elephant grass sugnesliog that bite giass contribured the bulk of low litire frations. This itnplies tbitt diet 3 rnight contsit mone digcstible corponerts thas the other two dicts. The wo(enis, ol' $\mathrm{Ca}, \mathrm{P}, \mathrm{Mg}_{e} \mathrm{~K}$ and hia in the experimenti:l dieks ate higlser tinar. the critical valles recono nacted tor sheep (MclJosell. 1985$)$ and the s s.

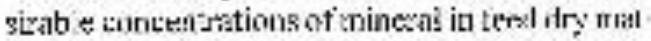
ter fur mainten ance yeconosendeai forr t:나 (SCA, 1990). This joplies tast the mineral conwents wolld be adediate at pnirwe powath in the anirsils. The ;rowe erergy in the concrimental diets ayen wit (hesworts $(.992)$ who reportenl thal. Ihe foross energy of most ariuxa! tiels is u.:ually ahout $18.5 \mathrm{MJ} / \mathrm{kg}$ DM.

For s.ll the pirameters examilled except NFE, whith incressyal, there was a goneral decline in aulsients as the leng:t of stcrage incsejsed truo: D is 90 days. The changes observed in ghln be lue io fluctuation in humitily ; wh tempsiature of the stornge covironnent becausc storage of the foccs was dons al nuors temperature. Aiso, the residunl troistuse (ahout $12 \%$ ) in the feed mughe sore presecoled conveniant ixcdiuis for micnobial degradation of inutriats in the stosed feres. III trease in DNt up to 30 days of shutage jodicated las of moisurc. However, the decrease in DMI content of the fieed atter 30 days of tanize indisates a declize in nutrient esm:ents of the feet duriog siorage (Jolirsox at al., 1984) Lathirm (1489) reported a doerease in dry mitter conteril of stored grasges with sabserputat increase it nor--tigcstible fravtions, In lize present study; the Lose of DM migh he d:e 2 loss of soxe of the 
digestible fraclioxls of the feed. This assertion is supeurlesilby llue aignificant docline in CP, CF. EE and aso cyorients of the stored fied. Oladotur et al. (2003) reported s similar seduction in C.P. C.F ind 1\%: In in it witage of ficot corsisting of Panicun rataximurr, peultry droppings, cossava peels ard youdas while the centerts of DM, ash, $\mathrm{Ca}$ anci $\mathrm{P}$ upprecialed wilh inciease in lengtio of storagce. The de:ire in $C F$, NIS, ADF and ADL as tic length of storige moreased naight be beceuto the consistency of the st nutaral curr:pontents of the feed is being losi uves lime (C)ladotun $e$. al., $26 \mathrm{n}$ ।. This loss in cons sient; would have beel facilicated by conversion of urie actid in ilue lasy. tas droppings to arrectija by ierubic bacteria (Nahun, 2003) takime advantage of te th ic uaticns in humidily and veingerature of the sturage envirorimelt. At the end of storags, the D.Y content of atoul yo " $\%$ is close to the walue reported by Oweo (1991), Tie CP olvtaincd in this stucy, is higher thin the level (II 12 \%iil rayuirod for moderate leve] of productiol by shecp (ARC, 1980; Getenby. 2002). The level of filve fraction in the teat dicts suggests that it would be sufteient to mest the fiber recuirements of the ruminants. Aiso, tl:e irinersl corcenurz.tion incticiales tlist the feeds would be adoquate lo meth the ptirueral requi rements of shcop (McDowel., 1985), 1te lenghth of stcrage used in thic study agreses with the retiumrnendation of oycdji (1996) (bas lewel slored or man: thas 90 days is old and sbot:k be te leased for fecding to ru:cinant aiminals

Pusiloolic ar cuble regression equation gare Lie

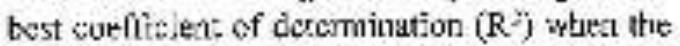
Lata on slorige weate firted to prodict the chexical compositjon o: the feeds beyoud 90 days ol storage. O on el iat, (1998) classiticd the goos-

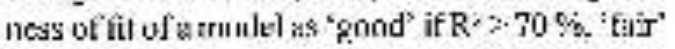
if $R^{2}, 70 \%$ bu $>40 \%$ and 'pow' if $^{2}<43 \%$ the level of $R^{2}$ observal for hF.. ash. NFE and ADL sinecs:s thit the [:arimelers could be used to presticl the fiuture cunlests of thesc contioinents of the feed the parameters could also be used to Jarly probicl Ile yield of C.P and D of the teed wher the feed is inkended to be storod tor morc tbare 90 days.

Protuktivity of cominaris is untinericed primarily by feed intake, which, in turcria is deter misted by tied digestibility and the iapacisy of the diet ke simply the correct balance of Dutrierits reulues: by the anmas. Feod intake in icis shuly is within

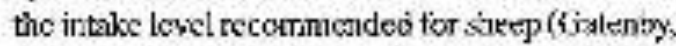
2002). Food and Agricultwal Organizution (1995)

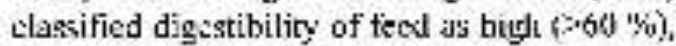
medium $(10-60 \%)$ and low $(-40 \%)$. Ln tus stuty. the apjarent digestibilicy osDML, CP, CF, ush, NDF; $A L I$ aru] $A D T$, were high cxecpt the mediucu value ublathed for $\mathrm{CF}$ in rams fed die: 3 and $\mathrm{NDF}$ in rars led djets 2 and 3. Dry matter digestibj.ity is sittin the $4970 \%$ reportad for sherp and goirs ted corobnations of elepiliant grass, poultry drop-

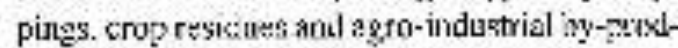

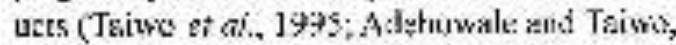

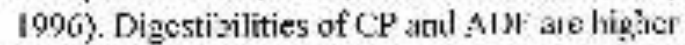
than $\angle 7.2 \%$ and $57.0 \%$. respec: lively reported by Taimo si wi. (1995 i howeve; digestihilily n?NDFF is lewer than the $6: .1 \%$ reported by lie same aurltoss. Tac significantly titfecent Co digestiaility it the rems for the experimentid diels wollil be: attributed to the CP contents of the tiels, I he ${ }^{\prime} I^{2}$ increased fiom $[7.14$ se ir dist ] to 18.73 we in thie: 3. It has been reported that maximus i liel ary c n ide: filuc digestion is the zunce occurs wben dielass CI is berween 12 and $16 \%$ dies (Pril:hard arul Mitles, 1985; stritzler. 3988; MwAlww. 1991) futreitsiag the level of CP in the diet beyoud to $6 \%$

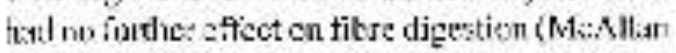
ed isi., 1482)- The properticn of sieplam giass and layers dtoppine signiticantly itleeted the digreslititity of ATDF. Overall, the arass: concens. trale ralin dosceased fiom diet I a dits 3.

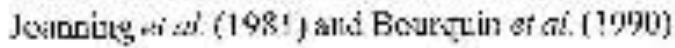




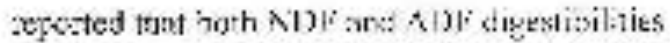
sereases es the dictary concertrate level in-

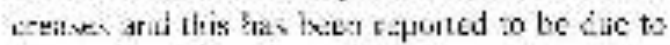
deyression of cannina $\mathrm{pH}$ in the wellier st et:

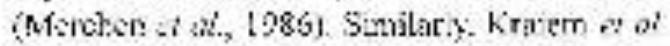

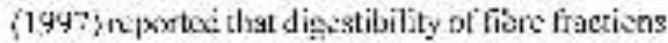

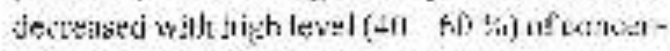
Inate supplenatation:s.

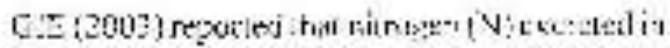

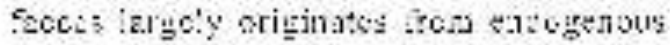

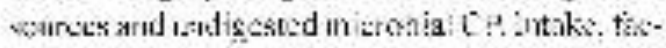

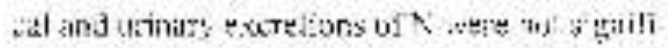
cails affeced by the crancits of poutty don-

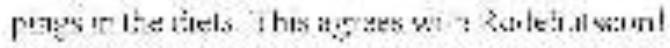

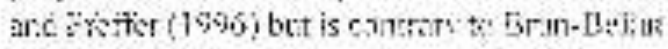

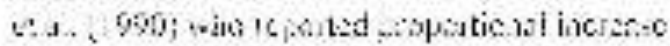

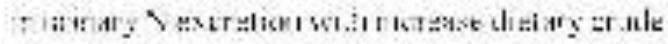
Fotem. Jta $\mathrm{h}$ ag $\mathrm{N}$ baines on the the ciets

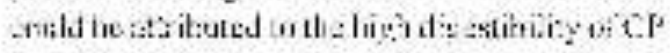

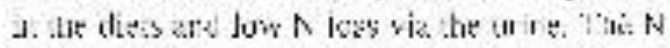

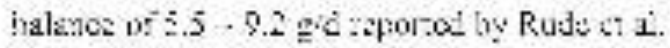

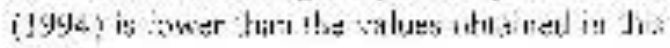
study

\section{Conclusion}

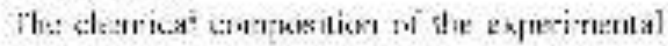
d.ets was alfected by sternge didec arrkien cond.tion witl: a rosuctis is the filerent cont

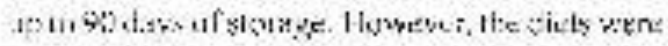

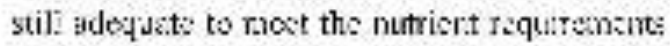

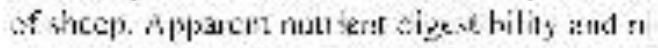

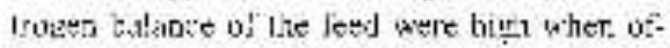
firod to sasp ard is indicative of tac nutitio

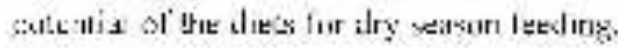

\section{Acknowledptement}

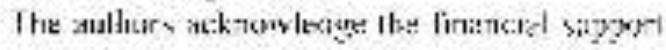
of $\mathrm{A}$. G. Levertis (Egboi and the colrcibutious of

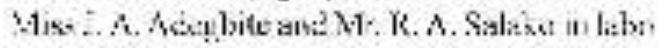
atcoy aralseis of strolyed

\section{References}

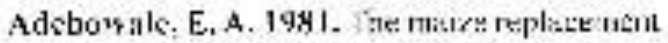

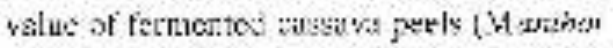

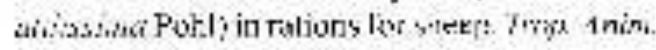
Privi: $5: 5-1-59$.

Adebrwaic, E.A. and Taiwo, A. A, 116/, ; ti

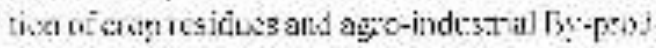

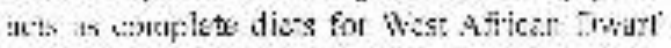

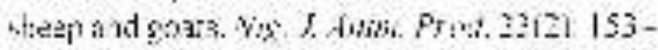
16).

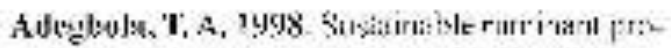

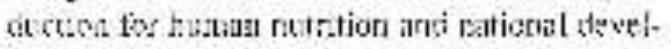

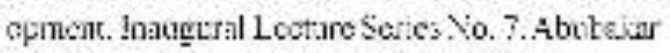

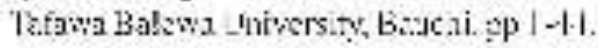

Adcebola. A.A. and Asaolu, 4. 1. 14.8h. Prexar.a

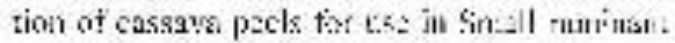

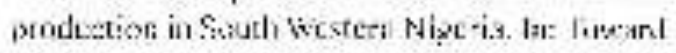

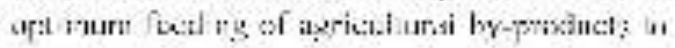
livestock in Afrea (Presten, i \& and

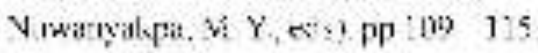

Adcjuma.J, O. und Aucnosud. A. A. 198S. F.ticet of plat age at harrest, and ol otting timet fiv-

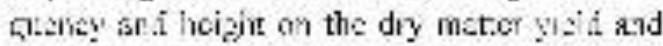

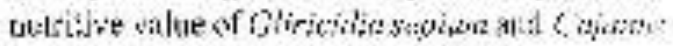
corion i dnim imal kes s(1) 1 is

A. O.A.C. (Association of Official Anajytical Clıcmistsi. 1990. Citficizl metinods of cuclysis. is" cätion. N.2shil:ster, DE, USA.

AKC: (Azricultural Leseareh (Council). 148!

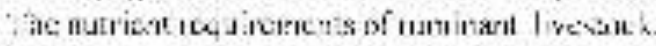

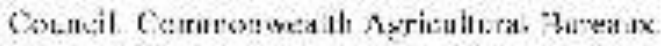
Shiseli, L...

1henт, "in, L. D., Gitrleb, K. A, Merchen, N, R.

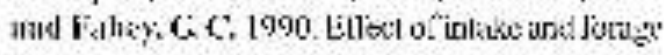
[avel 7 si.e and axt-nt of cigestion of plan. a ]l 
wall nomemeric components by diect. $J$. Antw. Sci $68: 2470-2195$.

Irun-Bellat, J., Blanchari, G. aad Viguon, B, 1990. F. Yect of rumen degriadah e woteir consentearion in dicts on digrestion, nitwogen utilization arul miik yicld by deiry guals. Small Ros! Rะ. $7: 575$ s81.

Chesrorth, J. 1992. Rujainant Nutizion. Tropical Ayricultural Sexics. Matmilan Pubtishers Ltd Losidon. pp 66 - 80 .

Davies,A. T, and Onwulin, C.IC L. 1993. Conservation of torse for dry season ferding in the loun:id zone of Vigeria In: Sustwibnible feod prelustion and tification for smaltholder livestock enterprises in. Sub Saharan Aärica. Proc, $2^{\text {ed }}$ A frigro fecd Resourze Network, Harar, Linulisawe. pp9i. 95 .

Duoan, D. K. I9SS Muliople range and muliple 1-rest. Biomeirics. 11: $;-24$.

FAO (Food und Agricultural Organization). 1995. Ifopical aninal teeding- A manual J ur reseasch workers. Find and Agricultural organization. Anirnal Psoducticat and llealth pape: Rome, Italy.

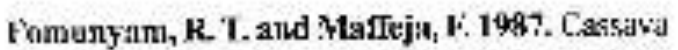
by-prod. acts in rabbit isul shoep dicts. In: Ltilizalion of asciculuaral by-produc:s as livestozk foed io Africa. (Ed) D.A. Litde and A. N. Seid ILCA, Addis Acaba. $p p$ : $01-: 07$

Fontenod, I. P. 1999. Nuricent roxyeling: The

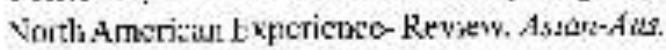
1. tnim, $\$ \times$ i. $12(6) 642-650$.

Gatealy, R. M. 2002. Sheep. Revised editjun. -xpital Agricultural Series. Mackillan Publjsit- ers I.t. Malaysia $\sqcap$ R.

GtE (Cesilschaft fur Eroahrubgspityslalogic). 21043. Recornureadetiors for the supply of enelgy and cut:ieols la goats. Energie-nind

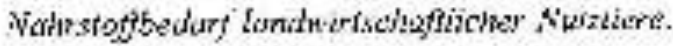
Nr. 9 DLGi-Ve-lag, Franktiut an Miin، pv 20.

Goering, H. K. ard Yun Soest, T. J. I970. Forate fibre unalysis (Apparatus, reagents. pritzerlures and gome applicarions). Agrie. Hunilhoren No. 378. ARTh-1TSDA. Washington, DC.

Jowning, S, W., Johnson, 1), V... and Barry, B. P. 1981. Nutrient digestibijity depression in corr:

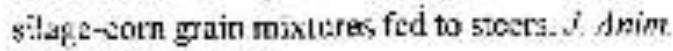
Sc. 5]: 109.91102.

Jobnson, D.G, Otterby, D. E., Lundquist, R. G, True, J.A. Benswn, F. A., Smith, R. $\mathbf{E}_{n}$ Lindor, $\mathbf{l}$. K. und Stommes, R.C., 1964, Yiéld snd quality of glfalfa as alleeled by barvesting antil stnrace methnds. I. Dairy Sri.67:2475 2180.

Kayongo.S. B., MYanywike, M. M., Mbugui, I. N., Mlaitho, T. E. and Nyaga. P. Y. 1545. Mcrfomaxx of weaner sheep ted whest straw ensile:] with caged larer wasts. las: Sustairlable faod production and utilization for smallho:der livesocs snterprises ir. Sub-Sahirab Africz. Proc. $2^{\text {st }}$ Africal Feed Resource Netwurh, Harare, Zirabubwe p pp $93-95$.

Kraient, Ku, Majdewb, A., Abbes, 5, B. ani Moujabed, N, 1997. Effects of the leved ofsupplementation with cercenteuts on the nutritive ind jtilization of calls has cur at throe nuturizy stages. Livestork Prod. Sci. $47 i^{7}$ : $175-$ 184. 
Laflnmme, L. F. 1499. tiffect of storage zondition fer large sound halcs on çualiog of griss. legutre

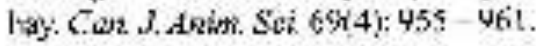

Manyuchi, II, Deb-I lowell, F. D., Ndlo*u, I $K_{ᄀ}$ Topps, J. H. and Tisgere, A. 1996. Fexting nap̧ier hay as supplements to shoxp given porir Luality

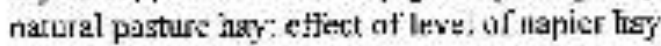
sepplement and inclutian of urea in the besal

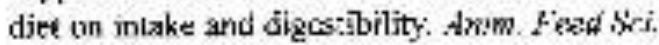
and Yicchnol. 63: $123-135$.

MtcAlian, A. B. 1991. Sources at ajtroges suppiements ti maxiraize cered copp tesitut dizesion

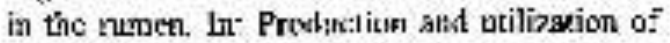
Jịnoceltalessics (Ciatlethi, (ì. C... ed). Elsevier Scieace Publishers 1.14, ringland. pp 375-385.

MeAllaa, A. B., Willinas, A, P., Merry, K.,C. aud Smilb, 1R. H. 1982. Eficer of dittienent level of cussio will or without fonmadibyde treatment on carbohydril= netaholism bstucen mouth and duodenum of slesrs, J, Secr, texed Asric. 33: 722728.

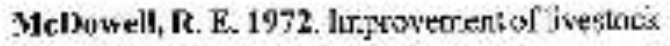
grodaction in warm cimatces. W. H. Freenilo iod Company, Sac F rancixes. pp I6S-21\%.

Mr:Doweli, L.R. 1985. Nutritis!n sif pasing ruminants in wam climstes. Äripternic P'vess lnc. San I Yıęu. Califomia. pp $168-169$.

Merchen, N, R, Virlcinx, I. L_and Rerger. L. L. 1986. Fffece of intake and forate level on minial lurnuver ratcs, bacterial proteir syrithesis and duvjens amino acid flow iu steep . I. Anjm Sr:i. 62:216 222 .

Mplairse, D. R, Sabiïti. E. N. and Mlugerwa, J.S. 1998, Eifect of dicd Girieldia zepriam Iril supplement on tieed intake, digestibility and nitrogen retentim in sheep fed dried KW4 sepinarit y,ass (

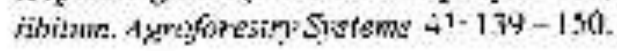

Mufler, Z O. 1980. liees from animal wastes: State or krowledge fard uná Agriculturai Organisation Animint Prextsctioli ond Measth Uagar Ix, Kotne. Jaly.

Vahus, K.H. 2003. Eviluaium sf the nitronen cantent in poultry sabuze. Worta's l'aatiry Science vournal 54: 7 ! - 88 .

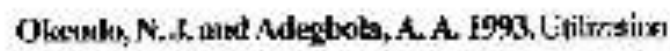
of dried cinget hem manure and easiava peels for intens:se shep production. Thop Anim filu Prod 25:230 238.

Oladulum, O. A, Aina, A, B. J. aad Ogumbari, F. B. 2003. Evaluatixı of fum wared agro-indugria! wastes as dry season. leed fur shesep. Nig. J. Anim. frod. ?o(1): $21-30$.

OWri, V. E., Brotherstone, S., Hill, W. Ci and Mef.iurk, H. J. 1998. Fit of staudard mode's of isctation curves 10 wekly reeord of milk pruduction of cows in a single hord. Ziwastocis Prot. Scr. 58:55 63.

Owen, J. 13. 1991. Cautla Fecding̣. $2 \cdot 1$ cdition. Fiarm Pycss Book. CK.

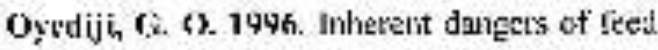
to!ling to the poultry intustry in Nageria. Pres: $z^{21}$

Anwaai Conf Nig Sor Anim Prinl. Ylyo. Nigeriu.

Pagot, J. 1992. Anisual I'reducrion in the Trecies

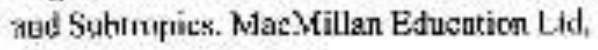
London. pp $418-427$. 


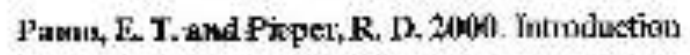

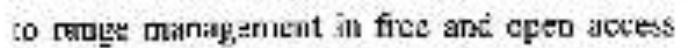
enviruluments of sub-sabinan $A$ frica. Sitmex and Express-Services. I)whang, Camcroon.

Pritclaard, R. H. und Nkales, I. R. 1985. Effisct of crude prodein and ri.minal ammonia nitroged un dizest.hilicy and rumer. outlow it heef canle fod whent bitu of anim Sci. $100: 822-831$.

Rodehutscord, [41, and Pfeffer, E. 1996. Bi-arizululue: air $\mathrm{V}$-Ausscheidung Lakiereoder -

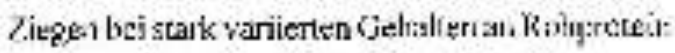

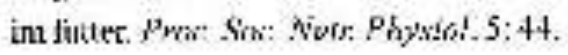

Rude, B. J., Runkins, I. L a ald Dowler, W. A. IHL 1994. Niltogen and encrgy metubolism asd iciun constimeas iu lamhs gives builer poultry processed by three deep stacking methods. Anim. Proil s8: $95-.01$.

Sarwer, M. und Nisa, UJ. M1. 1999. Eftiect o: nitroger: fertilization and stage of maturil 5 of Motterass (Yennisetwon gurgur:um) on ins themical coenposizion, dry inatter irtake, rumisal characteristies and diestibility in ballalo bu ls. Asim-Aus J. Anim, S<\%, 12(T): $1035-1039$.
SCA (Stmendarid Costmittee on Agricul(ure). 1990. Ferefing, Sliandard for Australian Livestock: Ru:tianals, Staindard Comuattee on A grieulture. CSIRO, Vlelboume.

Sursude, O.S, Akialcyc; B. C., Ugantipe, B, A. and Idom o, 0, M], O 2002. Nutrivive Poteritial sof sawdust îrom urixed wond spocies. Io: Adelor. V. A. ars Onibi, Gi A (cds.). Increusirg housebuld protein corisumption rlefough insprover livesta:k

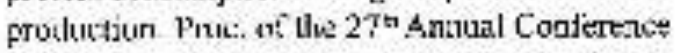
of the Kigerian Society for Animal Production, Ji. [I. T.A., Akure, Vizzeria.

5PSS, 1999, Slalistical P'avkage for Sosia\} Scierces Procedures and faci.itics for telease.

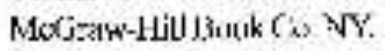

Stritzler, N, $\mu, 1958$. Tle zffect of cerey und proteia suppletors ation an dhe cigestion of̈nonstarch polysucthiariles ited microbia' activity ia the rasuen of cow's ied zibe-rich dicts. Pt.D. Thesis. The Royal Velterimary and Agriculnual Utirrisity. Copentager, Dejınark.

Talvon, A.A., Adebowule, E. A., tkinsoyinu, t. O. and Gucenhakh, J. F. D. 1995. Cinongeratire sudy on the use of four protein supplentents by thetil Africa o Dhwalf(WAD) shoep. Wigg. I Anim. Prod $221 \div 68-75$.

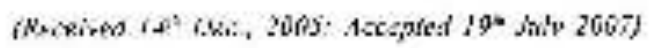

